GADOTTI, GI; HORNKE, NF; CAVALCANTE, JA; SILVA, JG; GONÇALVES, VP; CAPILHEIRA, AF. 2020. Efficiency of the gravity table in the processing of coriander seeds. Horticultura Brasileira 38: 211-216. DOI - http://doi.org/10.1590/S0102-053620200214

\title{
Efficiency of the gravity table in the processing of coriander seeds
}

\author{
Gizele Ingrid Gadotti ${ }^{1} \mathbb{D}$; Nander F Hornke ${ }^{1} \mathbb{D}$; Jerffeson A Cavalcante ${ }^{1} \mathbb{D}$; Joseano G da Silva ${ }^{1} \mathbb{D}$; Vanessa \\ P Gonçalves ${ }^{1} \mathbb{D}$; André F Capilheira ${ }^{1 \mathbb{D}}$
}

'Universidade Federal de Pelotas (UFPel), Pelotas-RS, Brasil, gizeleingrid@gmail.com; nanderhornke@gmail.com; jerffeson_agronomo@ hotmail.com; joseano_agronomo@outlook.com; vanessa_fito@gmail.com; capilheira@hotmail.com

\begin{abstract}
This study aimed at assessing the quality of the physiology and health of the coriander seeds processed in a gravity table. This was investigated at two settings namely, I with angle $\mathrm{X} 3.5^{\circ}$ and angle Y $3.1^{\circ}$ and II with $3.9^{\circ}$ and $2.7^{\circ}$ angles, with five gravity table discharges (high, high intermediate, intermediate, low intermediate and low) besides feeding. The experiment adopted the $2 \times 6$ factorial scheme, in a completely randomized design, with four replications. Two coriander seed batches of cultivar Verdão were used. The gravity table was adjusted to have $2.9 \mathrm{~m} \mathrm{~s}^{-1}$ air speed on the platform. The seed fractions discharged in the lower portion of the gravity table revealed poorer physiological performance than that of the others. Regulation I (angle $\mathrm{X} 3.5^{\circ}$ and $\mathrm{Y} 3.1^{\circ}$ ) was sufficient for the coriander seeds to be processed in batch 1 and regulation II (angle X $3.9^{\circ} \mathrm{Y}$ and $2.7^{\circ}$ ), was adequate for batch 2 . The processing of batch 1 in regulation II was effective in separating seeds of higher sanitary quality by rejecting the contaminated ones.
\end{abstract}

Keywords: Coriandrum sativum, separation, specific mass, physiological quality.

\section{RESUMO}

Eficiência da mesa de gravidade no beneficiamento de sementes de coentro

Objetivou-se avaliar a qualidade fisiológica e sanitária de sementes de coentro beneficiadas em mesa de gravidade. Estudaramse duas regulagens, sendo I com ângulo $\mathrm{X}$ de $3,5^{\circ}$ e Y de $3,1^{\circ}$ e II $3,9^{\circ}$ e $2,7^{\circ}$, e cinco descargas da mesa de gravidade (alta, intermediária alta, intermediária, intermediária baixa e baixa) além da alimentação, arranjados em esquema fatorial $2 \times 6$, no delineamento inteiramente casualizado, com quatro repetições. Foram utilizados dois lotes de sementes de coentro cultivar Verdão e a mesa de gravidade foi ajustada com velocidade do ar de $2,9 \mathrm{~m} \mathrm{~s}^{-1}$ na plataforma. As frações de sementes descarregadas na parte baixa da mesa de gravidade apresentaram desempenho fisiológico inferior à das demais. A regulagem $\mathrm{I}$ (ângulo $\mathrm{X}$ de $3,5^{\circ} \mathrm{e} \mathrm{Y}$ de $3,1^{\circ}$ ) foi adequada para o beneficiamento das sementes de coentro do lote 1 e a regulagem II (ângulo $\mathrm{X}$ de $3,9^{\circ}$ e $\mathrm{Y}$ de $2,7^{\circ}$ ), para o lote 2 . O beneficiamento do lote 1 na regulagem II foi eficiente na separação de sementes com melhor qualidade sanitária, pela remoção de sementes contaminadas.

Palavras-chave: Coriandrum sativum, separação, massa específica, qualidade fisiológica.

\section{Received on June 14, 2019; accepted on April 28, 2020}

$\mathrm{C}^{\mathrm{c}}$ oriander (Coriandrum sativum, Apiaceae), is an extensively consumed condiment vegetable with an annual cycle. It is popularly grown in Brazil, where a great number of producers participate in its exploitation, thus ensuring that it is a culture of significant socioeconomic value (Souza et al., 2011). Its leaves and fruits find use in the condiment industry and alcoholic beverage factories (Pereira et al., 2011).

In order to satisfy the high demand, superior quality seeds need to be made available in the market, which can be used to raise vigorous plants, capable of very good performance in the field. However, to produce such high-quality seeds, the field conditions where the plants are raised, develop and form new embryos, must be as close to ideal as possible (Almeida et al., 2016). When they are exposed to field conditions, several factors affect the plants, and these vary within the seed production fields.

Once the seeds harvested from the production field are well dried, they are processed to obtain high-quality seeds (Peske et al., 2012). At this stage, a few precautions are mandatory to avoid mechanical injuries, in particular, and enhance the physiological performance of the seed batch by typically employing the gravity table (Lopes et al., 2011; Silva et al., 2011).

In the seed processing line, the gravity table is the last machine used with the specific aim of separating the seeds of lower and higher specific mass, because of the close relationship present between the specific mass of a seed and its physiological quality. Seeds at different maturation stages, malformed, affected by insect attack or infected by microorganisms, show differences in their specific mass and can thus be easily rejected (Peske et al., 2012). The elimination of seeds of lower specific mass via the gravity table has been proven to be an efficient method for the processing of several plants, such as kale broccoli (Gadotti et al., 2006), tobacco (Gadotti et al., 2012) and castor bean (Drumond et al., 2019), This enables improved physiological performance of the seed batches (Pereira et al., 2012; Moreano et al., 2013; Drumond et al., 
2019).

In light of the facts mentioned and the paucity of data on coriander seed production, this study was done to determine the proficiency of the gravity table in the coriander seed processing, with the focus being the changes occurring in the physiological and sanitary performance of each of the batches.

\section{MATERIAL AND METHODS}

This work was accomplished at the Seed Processing Unit (UBS) of Embrapa Terras Baixas and in the Didactic Seed Laboratory of the Faculty of Agronomy Eliseu Maciel, of the Federal University of Pelotas, Campus Capão do Leão, RS. Two batches of coriander cultivar Verdão seeds were employed, produced in Candiota-RS, during the 2017 harvest. Two adjustments and five discharges from the gravity table plus feeding were investigated, adopting the $2 \times 6$ factorial scheme, in a completely randomized design, which included four replications. The identical statistical procedure was utilized for both seed batches.

After the seeds were dried and cleaned in an air machine, the same were sieved at Embrapa's UBS. Later, seeds were placed in a gravity table with the discharge being separated into five fractions (high, high intermediate, intermediate, low intermediate and low) besides the feed, which functioned as a witness or control (Figure 1). An 18-cm distance was maintained between each discharge.

The gravity table was adjusted, as follows: one (I) with $\mathrm{X}$ angle of $3.5^{\circ}$ and $3.1^{\circ}$ and the other (II) with $3.9^{\circ}$ and $2.7^{\circ}$, both provided with $2.9 \mathrm{~m} \mathrm{~s}^{-1}$ air speed on the platform. At each discharge four seed samples were drawn into containers of known volume. They were weighed to confirm the differences in the specific masses of the different discharges from the table. Post collection, seeds were transported to the laboratory, where the coriander seed quality in terms of the physical, physiological and health aspects were determined employing the following tests: a) Germination: for each treatment four repetitions of 50 seeds were used, sown onto two "blotting paper" sheets, moistened prior with distilled water equal to 2.5 times the dry paper mass, and packed in gerbox boxes. These boxes were then placed in a germinator, at $20^{\circ} \mathrm{C}$ temperature. At 21 days post sowing they were evaluated (Brasil, 2009a). The results were expressed as the percentage of normal seedlings.

b) First germination count: done along with the germination test, with the normal seedlings being counted seven days post sowing. The results were expressed as the percentage of normal seedlings (Brasil, 2009a).

c) Accelerated aging test: done in "gerbox" type acrylic boxes provided with a metallic screen. Each box contained $40 \mathrm{~mL}$ distilled water and the seeds were evenly distributed in a single layer on the screen. The boxes were then covered and kept in a BOD chamber, at $41^{\circ} \mathrm{C}$ for 48 hours. Finally, the seeds were submitted to germination test and seven days after sowing, evaluation was performed (Marcos Filho, 2015). The results were expressed as percentage of normal seedlings.

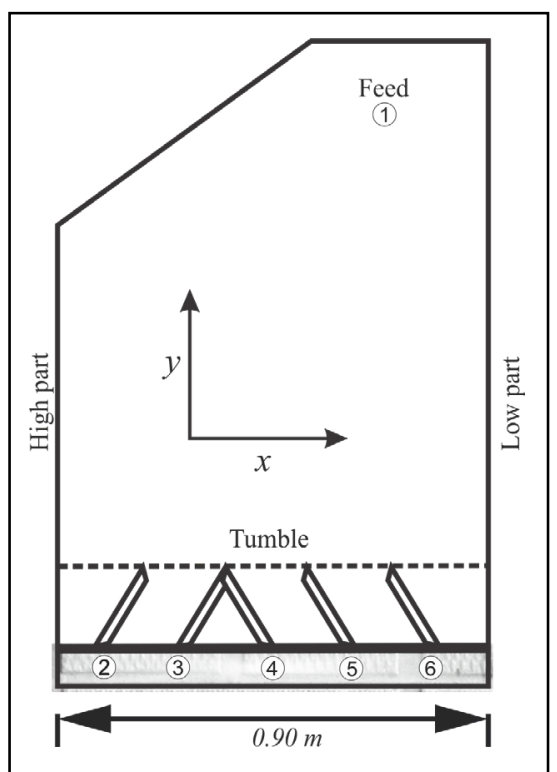

Figure 1. Sketch of the gravity table Oliver Gravity Separator used during the conduction of the experiment. 1: feed; 2: high discharge; 3: high intermediate discharge; 4: intermediate discharge; 5: low intermediate discharge and 6: low discharge. Pelotas, UFPel, 2019. d) Emergency on a bed: 400 seeds were sown in four rows, each with 100 seeds. Post sowing, the soil moisture (sandy clay) was maintained at field capacity. Evaluations were done in a single count, 21 days post sowing. The results are expressed in percentage of the emerged seedlings.

e) Health quality assessment: This evaluation was done employing the "blotter-test" method (Brasil, 2009b), using eight replicates of 50 seeds per treatment, which were incubated at $25^{\circ} \mathrm{C}$, with a 12 -hour photoperiod for seven days. When the incubation period was completed the seeds were examined under a stereomicroscope and, when required, slides were prepared for pathogen identification. The results were expressed in average values of the main fungi detected in each seed sample.

When the data were analyzed for normality and homoscedasticity it was clear that data transformation was not necessary. After analysis of variance $(p<0.05)$, with significance detected by the " $F$ " test, averages of the settings and discharges from the table were compared using Tukey test. The statistical analysis was done using the software R $\subset$ (R Core Team 3.5.1, 2018). The sanitary quality results were then subjected to descriptive statistical analysis, where only the averages were compared, according to Gadotti et al. (2012) and Meneses et al. (2018).

\section{RESULTS AND DISCUSSION}

The difference in specific mass of the coriander seeds between the high and low portions of the gravity table was in the range of 14.4 to $21.6 \%$ between batches 1 and 2, for settings I and II. Typically, depending on the seed, a wellregulated gravity table should provide a minimum of at least $7 \%$ difference in volumetric weight between the extreme fractions (Peske \& Baudet, 2012). In this study, the difference, on average, was $18 \%$ between the high and low discharges from the table.

Before being processed in the gravity table (feed), the coriander seeds from batches 1 and 2 had $80 \%$ and $77 \%$ germination rates, respectively 
(Table 2), which exceeded the values established by the legislation for the sale of coriander seeds, namely $65 \%$, according to the IN $\mathrm{N}^{\circ} 42$ of 2019 (Brasil, 2019).

After acconditioning, the batch 1 seeds showing germination in the high, intermediate high, intermediate discharges, as well as in the feed, revealed a higher degree of viability when compared with the seeds of the low and low intermediate discharges (Table 2). In regulation I they displayed inferior germination from the low and low intermediate discharges when compared with those of regulation II.

Concerning the seeds from batch 2 and regulation I, no difference was noted in terms of the germination from the high discharge to low intermediate. However, the same result was not true for those seeds from the lower portion of the table. In regulation II, the low and low intermediate discharges revealed seeds having a lower degree of germination when compared to the other discharges from the table. However, no difference was observed between the two settings (Table 2).

In terms of acquiring seeds having higher germination via the gravity table for separation, results corresponding to those of this work were also observed for broccoli (Gadotti et al., 2006), brachiaria (Hessel et al., 2012) and tobacco (Gadotti et al., 2012). This shows the efficiency of the gravity table in enhancing the viability of a batch of seeds for processing.

During the assessment of the first germination count (PCG) of batch 1 and regulation $\mathrm{I}$, the seeds from the low and low intermediate discharges were observed to have less vigor than those from the regulation for the same discharges. The seeds separated in regulation I displayed the same PCG in the high, intermediate high, intermediate and feed discharges; however, the seeds from the low and low intermediate discharges revealed less vigor when compared to the other discharges and the feed (Table 2). However, in regulation II, both batches were not stratified at different vigor levels when the first count test was used. This was because the different discharges, revealed similar vigor, although the average mass difference was 20.5 and $15.5 \%$, respectively, between the high and low portions of the gravity table (Table 1).

In fact, Gadotti et al. (2012) reported similar PCG results; therefore, when determining the effect exerted by the different settings on the gravity table on the tobacco seed quality, they observed no differences between the different discharges from the table, irrespective of the setting; however, on comparing the different settings, differences were noted between them. Thus, because the PCG was performed concomitantly with the germination test, the prevailing humidity and optimum temperature conditions for the species being investigated may have benefited a high degree of medium vigor.

In the accelerated aging test (Table 2), no significant effect was noted for regulation on seed quality for both batches. However, in batch 1 , the seeds were segregated into three levels of vigor: more vigorous (high and intermediate high discharge); of medium vigor (low intermediate and intermediate discharge); and finally, the seeds with less vigor (from the low discharge part). On the contrary, batch 2 showed stratification into more vigorous (high and intermediate high discharges) and less vigorous (low table discharge) (Table 2). The results of the accelerated aging test are justified by the fact that lower specific mass is generally indicative of being linked to

Table 1. Difference of specific mass between the high and low part, in percentage, between the discharges of the gravity table adjusted with two adjustments, during the processing of two coriander seed batches. Pelotas, UFPel, 2019.

\begin{tabular}{|c|c|c|c|c|c|c|c|c|c|c|}
\hline \multirow{3}{*}{ Discharge } & \multicolumn{10}{|c|}{ Batch 1} \\
\hline & \multicolumn{5}{|c|}{ Adjustment $I\left(X=3.5^{\circ}\right.$ and $\left.Y=3.1^{\circ}\right)(\%)$} & \multicolumn{5}{|c|}{ Adjustment II $\left(\mathrm{X}=3.9^{\circ}\right.$ and $\left.\mathrm{Y}=2.7^{\circ}\right)(\%)$} \\
\hline & $A^{*}$ & IA & I & IB & B & $\mathbf{A}$ & IA & $\mathbf{I}$ & IB & B \\
\hline A & 0.0 & - & - & - & - & 0.0 & - & - & - & - \\
\hline IA & 4.2 & 0.0 & - & - & - & 3.7 & 0.0 & - & - & - \\
\hline I & 4.1 & 0.4 & 0.0 & - & - & 3.0 & 2.0 & 0.0 & - & - \\
\hline IB & 8.4 & 9.7 & 6.6 & 0.0 & - & 5.2 & 1.6 & 2.6 & 0.0 & - \\
\hline \multirow[t]{2}{*}{ B } & 20.5 & 14.1 & 16.6 & 16.7 & 0.0 & 14.4 & 9.3 & 9.0 & 6.0 & 0.0 \\
\hline & \multicolumn{10}{|c|}{ Batch 2} \\
\hline A & 0.0 & - & - & - & - & 0.0 & - & - & - & - \\
\hline IA & 2.2 & 0.0 & - & - & - & 0.7 & 0.0 & - & - & - \\
\hline I & 1.2 & 1.0 & 0.0 & - & - & 5.1 & 5.6 & 0.0 & - & - \\
\hline IB & 4.5 & 1.1 & 4.1 & 0.0 & - & 7.0 & 0.7 & 0.7 & 0.0 & - \\
\hline B & 15.5 & 14.1 & 14.5 & 10.7 & 0.0 & 21.6 & 16.9 & 16.9 & 13.3 & 0.0 \\
\hline
\end{tabular}

*The discharges described in the line correspond to the values that presented the greatest weight difference. A: high; IA: high intermediate; I: intermediate; IB: low intermediate; B: low. 
low viability and seed vigor (Hessel et al., 2012).

The seedling emergence from batch 1 benefited in the gravity table with regulation I facilitated stratification in three levels of vigor, showing a 12- and $23 \%$-rise in the seedling emergence, with the high and low discharges of the feed, respectively. In regulation II, almost no difference was observed between the high discharge, high intermediate and intermediate discharges, and they were superior to the low and low intermediate discharges, apart from feeding. According to Cantarelli et al. (2015), high physiological quality seeds will facilitate greater speed in plant emergence, larger plant stands and higher degree of stand uniformity.

For batch 2 and regulation I, the seeds from high to intermediate discharges revealed a higher percentage of emergence compared to the seeds from the low and low intermediate discharges, besides differing from the feed. Regarding the seeds, which acconditioned in regulation II, a higher degree of superiority was noted in the seedling emergence from high discharge compared to those from the intermediate, low, low and feeding discharges (Table 2).

Batch 1 seeds, acconditioned in regulation II (Table 2 ), revealed a higher emergence percentage in the high intermediate, intermediate and low intermediate discharges. However, the batch 2 seeds, benefited in regulation I, showed a lower percentage of emergence in the intermediate, low and low intermediate discharges (Table 2).

Results which concurred with those of this work were reported by Melo et al. (2018), in their assessment of the effects of the acconditioning phases on the physical and physiological quality of Panicum maximum x P. infestum, cv. Massai seeds in terms of marketing value, which achieved $68 \%$ emergency $(p>0.05)$. Similarly, identical results were reported for soybean (Silva et al., 2011), rice (Pereira et al., 2012), brachiaria seeds (Hessel et al., 2012) and castor bean (Drumond et al., 2019).

From the results observed in terms of viability and vigor (Table 2), the seeds drawn from the high and high intermediate discharges in the gravity table would be appropriate for treatment, storage and other processes; however, the seeds from the low discharge could be rejected. In fact, the seeds taken from the low intermediate and intermediate discharges in the gravity table showed no change in the percentages of germination and vigor compared to those that supplied the equipment, and could be passed again in the equipment with new regulation.

The seeds collected in the feeding zone had a higher fungal presence than did most of the fractions achieved in the unloaded gravity table zone (Table 3 ), reiterating the necessity to stratify these seeds to get higher specific mass and better quality. Aspergillus spp. was present in the seeds from regulation I of batch 2 (Table 3), which was perhaps

Table 2. Germination, first germination count (PCG), accelerated aging and emergence in bed of two batches of coriander seeds acconditioned in gravity table with two adjustments and five discharges. Pelotas, UFPel, 2019.

\begin{tabular}{|c|c|c|c|c|c|c|c|c|}
\hline \multirow{3}{*}{ Discharge } & \multicolumn{8}{|c|}{ Batch 1} \\
\hline & \multicolumn{2}{|c|}{ Germination (\%) } & \multicolumn{2}{|c|}{ PCG (\%) } & \multicolumn{2}{|c|}{ Aging (\%) } & \multicolumn{2}{|c|}{ Emergency (\%) } \\
\hline & Reg. 1 & Reg. 2 & Reg. 1 & Reg. 2 & Reg. 1 & Reg. 2 & Reg. 1 & Reg. 2 \\
\hline A & $85 \mathrm{aA}^{*}$ & $84 \mathrm{aA}$ & $74 \mathrm{Aa}$ & $78 \mathrm{aA}$ & $82 \mathrm{~A}$ & $83 \mathrm{~A}$ & $70 \mathrm{Bab}$ & $78 \mathrm{aAB}$ \\
\hline IA & $82 \mathrm{aA}$ & $85 \mathrm{aA}$ & $65 \mathrm{Ab}$ & $77 \mathrm{aA}$ & $75 \mathrm{AB}$ & $83 \mathrm{AB}$ & $76 \mathrm{Aa}$ & $78 \mathrm{Aab}$ \\
\hline I & $82 \mathrm{aA}$ & $83 \mathrm{aA}$ & $70 \mathrm{Aa}$ & $74 \mathrm{aA}$ & $72 \mathrm{AB}$ & $71 \mathrm{AB}$ & $65 \mathrm{bAB}$ & $71 \mathrm{aABC}$ \\
\hline IB & $72 \mathrm{bB}$ & $79 \mathrm{aA}$ & $50 \mathrm{Bb}$ & $69 \mathrm{aA}$ & $71 \mathrm{AB}$ & $71 \mathrm{AB}$ & $62 \mathrm{bBC}$ & $79 \mathrm{Aa}$ \\
\hline B & $63 \mathrm{bC}$ & $79 \mathrm{aA}$ & $40 \mathrm{Bb}$ & $73 \mathrm{aA}$ & $63 \mathrm{~B}$ & $65 \mathrm{~B}$ & $53 \mathrm{bC}$ & $67 \mathrm{aBC}$ \\
\hline Feed & $80 \mathrm{aA}$ & $80 \mathrm{aA}$ & $71 \mathrm{Aa}$ & $71 \mathrm{aA}$ & $73 \mathrm{AB}$ & $73 \mathrm{AB}$ & $64 \mathrm{aBC}$ & $64 \mathrm{aC}$ \\
\hline Average & 77.3 & 81.7 & 63.3 & 73.8 & 72.6 & 74.3 & 65.0 & 72.8 \\
\hline \multirow[t]{2}{*}{ CV (\%) } & \multicolumn{2}{|c|}{4.61} & \multicolumn{2}{|c|}{6.99} & \multicolumn{2}{|c|}{7.83} & \multicolumn{2}{|c|}{6.99} \\
\hline & \multicolumn{8}{|c|}{ Batch 2} \\
\hline $\mathrm{A}$ & $83 \mathrm{aA}$ & $87 \mathrm{aA}$ & $77 \mathrm{Aa}$ & $78 \mathrm{aA}$ & $81 \mathrm{~A}$ & $81 \mathrm{~A}$ & $70 \mathrm{bAB}$ & $78 \mathrm{aAB}$ \\
\hline IA & $81 \mathrm{aA}$ & $87 \mathrm{aA}$ & $75 \mathrm{Aab}$ & $77 \mathrm{aA}$ & $77 \mathrm{AB}$ & $78 \mathrm{~A}$ & $76 \mathrm{aA}$ & $78 \mathrm{Aab}$ \\
\hline I & $80 \mathrm{aA}$ & $85 \mathrm{aA}$ & $69 \mathrm{Aa}$ & $74 \mathrm{aA}$ & $73 \mathrm{AB}$ & $71 \mathrm{~A}$ & $65 \mathrm{bAB}$ & $71 \mathrm{aABC}$ \\
\hline IB & $80 \mathrm{aA}$ & $78 \mathrm{aB}$ & $45 \mathrm{bC}$ & $69 \mathrm{aA}$ & $74 \mathrm{AB}$ & $69 \mathrm{~A}$ & $62 \mathrm{bBC}$ & $79 \mathrm{Aa}$ \\
\hline B & $73 \mathrm{aB}$ & $76 \mathrm{aB}$ & $39 \mathrm{bC}$ & $72 \mathrm{aA}$ & $63 \mathrm{~B}$ & $67 \mathrm{~A}$ & $53 \mathrm{bC}$ & $67 \mathrm{aBC}$ \\
\hline Feed & $77 \mathrm{aAB}$ & $77 \mathrm{aB}$ & $70 \mathrm{aB}$ & $70 \mathrm{aA}$ & $69 \mathrm{AB}$ & $69 \mathrm{~A}$ & $64 \mathrm{aBC}$ & $64 \mathrm{aC}$ \\
\hline Average & 79.0 & 81.6 & 62.5 & 73.3 & 72.8 & 72.5 & 65.0 & 72.8 \\
\hline CV (\%) & \multicolumn{2}{|c|}{3.44} & \multicolumn{2}{|c|}{6.18} & \multicolumn{2}{|c|}{10.51} & \multicolumn{2}{|c|}{6.99} \\
\hline
\end{tabular}

* Means followed by the same lowercase letter in the line and uppercase in the column, do not differ by Tukey test at 5\% error probability. A: high; IA: high intermediate; I: intermediate; IB: low intermediate; B: low charging. 
Table 3. Sanitary quality in two batches of coriander seeds acconditioned in a gravity table with two adjustments and five discharges. Pelotas, UFPel, 2019.

\begin{tabular}{|c|c|c|c|c|c|c|c|c|c|c|c|}
\hline \multirow{3}{*}{ Pathogens } & \multirow{3}{*}{ Feed } & \multicolumn{10}{|c|}{ Batch 1} \\
\hline & & \multicolumn{5}{|c|}{ Adjustment I } & \multicolumn{5}{|c|}{ Adjustment II } \\
\hline & & $\mathbf{A}$ & IA & I & IB & B & $\mathbf{A}$ & IA & I & IB & B \\
\hline Alternaria alternata & 40 & 19 & 19 & 19 & 16 & 16 & 25 & 33 & 34 & 43 & 39 \\
\hline Alternaria dauci & 4 & 1 & 1 & - & 1 & 2 & - & 2 & 2 & 3 & 2 \\
\hline Fusarium sp. & 16 & 3 & 6 & 5 & 6 & 3 & 9 & 9 & 12 & 15 & 13 \\
\hline Aspergillus sp. & 1 & 3 & - & 1 & - & 2 & 7 & - & - & - & 1 \\
\hline \multirow[t]{2}{*}{ Nigrospora sp. } & 3 & 2 & 3 & 3 & 3 & 2 & 1 & 2 & 2 & 2 & 2 \\
\hline & & \multicolumn{10}{|c|}{ Batch 2} \\
\hline Alternaria alternata & 44 & 32 & 32 & 31 & 28 & 33 & 48 & 47 & 42 & 41 & 41 \\
\hline Alternaria dauci & 2 & 2 & 4 & 2 & 2 & 2 & 2 & 2 & 2 & 2 & 3 \\
\hline Fusarium sp. & 14 & 11 & 11 & 11 & 11 & 10 & 24 & 19 & 18 & 13 & 10 \\
\hline Aspergillus sp. & - & - & - & - & - & - & 2 & 2 & 1 & - & 2 \\
\hline Nigrospora sp. & 2 & 1 & 2 & 1 & 2 & 1 & 2 & 2 & 4 & 2 & 2 \\
\hline
\end{tabular}

*A: high, IA: high intermediate, I: intermediate, IB: low intermediate, B: low charging. The data are presented in numbers (without transformation or unit of measure).

because some field fungi inhibit, at least partially, the activity of those propagating skins that may be associated with the seeds from the field. However, a high incidence of Aspergillus spp. in the batch 1 seeds drawn from the high discharge in the gravity table, adjusted in regulation II. Although they are not pathogenic to the seedlings, the Aspergillus spp. is one of the principal agents of deterioration of the seeds, which can release mycotoxins and speed up the deterioration rate in the storage period (Brasil, 2009b).

In light of the fact that the seeds drawn from the low and low intermediate discharges are normally rejected during acconditioning (Almeida et al., 2016), the removal of the contaminated coriander seeds containing Alternaria alternata in batch 1 and regulation II (Table 3) was found to be efficient. Besides, the removal of this fungal species during processing is one of the eradication steps that needs to be adopted in an effective disease management program for vegetables. Identical results were noted in the removal of $A$. dauci from the low discharge seeds from the table (Table 3). Such fungi commonly occur in carrot and coriander seeds, most often adherent to the thin, kind of long and rigid structures, as evident in aristas (Poudel \& Zhang, 2018). Therefore, the presence of these structures in the coriander seeds may have encouraged the permanence of the $A$. dauci in the seeds until processing, and subsequently, cause economic damage to the plants in the field, inducing leaf burn and finally the destruction of the aerial plant parts.

Seeds from the intermediate discharges in regulation II revealed a stronger presence of Fusarium sp. (Table 3). The high and intermediate high discharges revealed numerically lower number of fungi. The $A$. alternata also demonstrated similar behavior, except for the seeds that were collected in the high discharge from the gravity table. According to Muniz et al. (2018), the Alternaria fungi were transported via seed through passive adhesion, which facilitated their propagules to be visible on some vegetables, on the surfaces.

In batch 2, for both settings, normally seeds drawn from the different discharges on the gravity table had decreasing fungal values, as they were taken from high to low discharges (Table $3)$. This suggested it was not always that the lighter seeds contained a higher quantity of the fungi. The results, in general, revealed the efficiency of the gravity table in removing materials with lower specific mass, thus enabling the seeds of higher physiological and sanitary quality to be obtained from the materials discharged in the upper part. Therefore, the coriander seed fractions discharged in the lower portion of the gravity table have a poorer physiological quality than that observed in the other discharges.

Regulation I (angle X of $3.5^{\circ}$ and $\mathrm{Y}$ of $3.1^{\circ}$ ) was sufficient for processing the coriander seeds in batch 1 and regulation II (angle X of $3.9^{\circ}$ and $\mathrm{Y}$ of $2.7^{\circ}$ ), for batch 2 . The acconditioning of batch 1 in regulation II is efficient in separating seeds possessing higher sanitary quality, by removal of the contaminated seeds.

\section{ACKNOWLEDGMENTS}

The authors extend their gratitude to the Coordination for the Improvement of Higher Education Personnel (CAPES) and the National Council for Scientific and Technological Development (CNPq) for the scholarships granted.

\section{REFERENCES}

ALMEIDA, TL; CAPILHEIRA, AF; CAVALCANTE, JA; SCHEUNEMANN, LC; PANOZZO, LE. 2016. Qualidade de sementes de soja beneficiadas em mesa de gravidade. Enciclopédia Biosfera 13: 1097-1106.

BRASIL. 2009a. Ministério da Agricultura, 
Pecuária e Abastecimento. Secretaria de Defesa Agropecuária. Regras para análise de sementes. Brasília, 395p.

BRASIL. 2009b. Ministério da Agricultura, Pecuária e Abastecimento. Secretaria de Defesa Agropecuária. Manual de Análise Sanitária de Sementes. Brasília: MAPA/ ACS. 200p.

BRASIL. Portaria SDA n ${ }^{\circ} 42$, de 17 de setembro de 2019. Normas para a Produção e a Comercialização de Sementes e Mudas de Espécies Olerícolas, Condimentares, Medicinais e Aromáticas e os seus padrões de sementes. Diário Oficial da União, Brasília, 17 de setembro de 2019. Seção 1. 6p.

CANTARELLI, LD; SCHUCH, LOB; TAVARES, LC; RUFINO, CA. 2015. Variabilidade de plantas de soja originadas de sementes de diferentes níveis de qualidade fisiológica. Acta Agronómica 64: 234-238.

DRUMOND, AAL; SALES, JDF; ZUCHI, J; CAMELO, GN; SOUZA, MMV. 2019. Qualidade fisiológica de sementes de mamona (Ricinus communis L.) após o beneficiamento. Journal of Seed Science 41: 224-232.

GADOTTI, GI; CORRÊA, CA; LUCCA FILHO, OA; VILLELA, FA. 2006. Qualidade de sementes de couve brócolis beneficiadas em mesa densimétrica. Revista Brasileira de Sementes 28: 123-127.

GADOTTI, GI; BAUDET, L; VILLELA, FA. 2012. Several regulations in gravity table in quality of tobacco seeds. Revista de Engenharia Agrícola 32: 361-368.

HESSEL, CLE; VILLELA, FA; AUMONDE, TZ; PEDÓ, T. 2012. Mesa densimétrica e qualidade fisiológica de sementes de brachiária. Informativo ABRATES 22: 73-76.

LOPES, MM; PRADO, MOD; SADER, R; BARBOSA, RM. 2011. Efeitos dos danos mecânicos e fisiológicos na colheita e beneficiamento de sementes de soja. Bioscience Journal 27: 230-238.

MENESES, PR; DORNELES, KR; BELLE, C; MOREIRA-NUÑEZ, VL; GONÇALVES, V; FARIAS, CRJ. 2018. First report of Cladosporium cladosporioides causing leaf spot on Alstroemeria aurea in Brazil. Plant Disease 102: 1849-1849.

MARCOS FILHO, J. 2015. Fisiologia de sementes de plantas cultivadas. 2ed. Londrina: ABRATES

MELO, LF; MARTINS, CC; SILVA, GZ; PEREIRA, FECB; JEROMINI, TS. 2018. Effects of processing phases on the quality of massai grass seeds. Revista Ciência Agronômica 49: 259-266.

MOREANO, TB, BRACCINI, AL; SCAPIM, CA; FRANÇA-NETO, JB; KRZYZANOWSKI, FC; MARQUES, OJ. 2013. Evolução da qualidade física de sementes de soja durante o beneficiamento. Informativo ABRATES 23: 23-31.

MUNIZ, PHPC; MARQUES, MG; PEIXOTO, GHS; SIMAO, KG; CARVALHO, DDC. 2018. Morphological characterization of Alternaria alternata associated on iceberg lettuce seeds cv. 'Astra'. Revista de Agricultura Neotropical 5: 82-86.

PEREIRA, CE; OLIVEIRA, JA; MARQUES, MC; KIKUTI, RALP. 2011. Armazenamento de sementes de braquiária peletizadas e tratadas com fungicida e inseticida. Ciência Rural 41: 2060-2065.

PEREIRA, CE; ALBUQUERQUE, SK; OLIVEIRA JA. 2012. Qualidade física e fisiológica de sementes de arroz ao longo da linha de beneficiamento. Semina: Ciências Agrárias 33: 2995-3002.

PESKE, ST; VILLELA, FA; MENEGHELLO, GE. 2012. Sementes: Fundamentos científicos e tecnológicos. Pelotas: Editora Universitária. $573 \mathrm{p}$.

PESKE, ST; BAUDET, LM. 2012. Beneficiamento de Sementes. In.: PESKE, ST; VILLELA FA; MENEGHELLO, GE (eds). Sementes: Fundamentos científicos e tecnológicos. v.3. Pelotas: Editora Universitária, UFPel, p.423-479.

POUDEL, B; ZHANG, S. 2018. First report of Alternaria leaf spot of cilantro (Coriandrum sativum) caused by Alternaria dauci in the United States. Plant Disease 102: 822-822.

R Core Team 3.5.1 - Latest Version. 2018. R: $A$ language and environment for statistical computing. R Foundation for Statistical Computing, Vienna: URL

SILVA, RP; TEIXEIRA, IR; DEVILLA, IA; REZENDE, RC; SILVA, GC. 2011. Qualidade fisiológica de sementes de soja (Glycine $\max$ L.) durante o beneficiamento. Semina: Ciências Agrárias 32: 1219-1230.

SOUZA, TV; ALKIMIM, ER; DAVID, AMSS; SÁ, JR; PEREIRA, GA; AMARO, HTR; MOTA, WF. 2011. Época de colheita e qualidade fisiológica de sementes de coentro produzidas no norte de Minas Gerais. Revista Brasileira de Plantas Medicinais. 13: 591-597. 